DOI https://doi.org/10.18551/rjoas.2020-11.21

\title{
SUSTAINABLE TOURISM: WHY DO GOVERNMENT NEED COLLABORATIVE GOVERNANCE?
}

\author{
Duadji Noverman*, Tresiana Novita \\ Department of Public Administration, Faculty of Social and Political Science, \\ University of Lampung,Indonesia \\ *E-mail: noverman.duadji@fisip.unila.ac.id \\ ORCID: 0000-0002-1459-8045
}

\begin{abstract}
The research aims to elaborate strategic dimensions in collaborative planning as the carrying capacity of government action in the success of sustainable tourism development policies. The criticism of the government's dominance in the tourism sector has marginalized the community and gave rise to psudo democracy. The research method uses descriptive qualitative, located in Pekon Wisata Teluk Kiluan, Tanggamus Regency. Indonesia. Data collection by interview, observation, and documentation study. The analysis uses a collaborative governance model. The results of the study elaborate on the strategic dimensions of collaborative governance in the form of participation, equality and community competence that require policy correction and a strategic part in tourism sustainability. Several supporting factors such as local culture, community education level, government dynamics in responding to change, deliberations for planning and regional development are useful in improving decision making in public policy.
\end{abstract}

\section{KEY WORDS}

Collaborative governance, sustainable tourism, policy planning.

The majority of literature and field studies on tourism show that tourism development in an area can have economic, social, political and environmental impacts (Ehigiamusoe,2020) as well as an instrument capable of producing a high multiplier effect for community welfare, if managed properly and sustainably (Khalid et all.,2019; Tresiana and Duadji, 2018).

This study is based on the issue of the government's failure in managing development, especially the tourism sector due to the wrong management planning model, which is very centralized, linear (top down) and makes the community the object of development, the government's economic targets, community marginalization occurs politically, culturally, economic, social, and environmental management that affect their lives (Cascante and Brennan,2011; Khalid et all., 2019; Ehigiamusoe, 2020).

The study, which was conducted in ten villages in South Lampung Regency, Indonesia, shows that the results of tourism development are not able to improve community welfare, are not in accordance with national issues regarding democracy, reform, participation and community empowerment seen from development planning (Tresiana and Duadji, 2016). The government failure study shows the tendency of psudo democracy, where community institutions are weak, only government institutions are strong, and the responsibility of local local governments to maximize the economic welfare of the community is weak. On the other hand, it seems that community loyalty is getting stronger and makes the community a source of security and economic opportunity. The above conditions result in the government's legitimacy getting weaker, it requires synergic collaboration, not psudo in the management of development, including the tourism sector (Fukuyama, 2005;Graci,2013).

This study focuses on strategic dimensions in collaborative planning as the carrying capacity of government action in sustainable tourism development policies. The importance of this is due to two major changes, namely the regional autonomy regulation which positions local governments to increase regional income, and sees the potential of the tourism sector as an instrument of achievement (Tresiana and Duadji, 2018). Changes in the perspective of conventional tourism management towards sustainability, a shift from high volume production 
of standard commodities to high-volume production of unque commodities (Khalid et all.,2019). The management of mass tourism by inviting and involving private and even foreign investors, excessive protection of the private sector, issuing many exclusive management permits, being very far from the reach of local communities, having an adverse social, economic and environmental impact, especially for local communities (Ehigiamusoe,2020). The criticism of government domination has linked it to a more ethical and democratic collaborative governance dimension (Anshell and Gash, 2008; Innes and Booher, 2010).

Many studies link tourism with institutional factors, top-down planning, transactivity (Khalid et all.,2019). However, it is still rare to link tourism with a collaborativebased planning approach. In relation to tourism-related planning, the planning paradigm has shifted towards collaboration-based development (Araujo and Bramwell,2009; Graci, 2013). One of the important elements of collaborative planning is the communication base. The previous perspective describes how planning is based on rational planning, which often ignores political realities. This then became the basis for Charles Lindbloom to put forward the idea of disjointed incementalism and Amitai Ezioni with the idea of Mixed-scanning (Tresiana, 2015). Despite the change in approach, the fact remains that planning only involves policy makers. The study conducted expresses thoughts about a transactive planning concept, structured based on a dialogue between the planner and his client. In the context of this study, planning is a form of application of knowledge into action and classifies planning as social reform, policy analysis, social learning, and social mobilization. This change in approach made planning not only belong to the government, but also to the community (Friedman, 2011)

Ansell and Gash (2008), Innes and Booher (2000), their study explains the strategic dimension as a prerequisite for the creation of a collaborative process of sustainable tourism governance, which minimizes the pseudo democracy, including, first, stakeholder participation. Actual participation is citizen power as stated in the ladder of participation according to Aronstein. Second, the conditions in which there is equality of power. This means that there is no domination by certain parties, each actor in dialogue is not hindered by hierarchical boundaries, and there is mutual respect. Third, competent actors. The dialogue that occurs must be a form of consensus-oriented communication, so that it requires supporting actors, in the sense of having competence in communicating, understanding the substance, and having an orientation to achieve goals for the common interest.

The aim of the study is to elaborate strategic dimensions that must be developed in collaborative governance of sustainable tourism. Recommendations for policy improvement studies, especially the framework for planning sustainable tourism development, based on government and community collaboration.

\section{METHODS OF RESEARCH}

The research was conducted by Pekon Teluk Kiluan which is located in Kelumbayan Barat Subdistrict, Tanggamus Regency. Indonesia, in April-August 2018. Descriptive qualitative methods are used to describe and elaborate data. Data collection was carried out by interview, observation, and documentation study. Collected collaborative governance data is reviewed through collaborative governance analysis from Ansell and Gash (2008), Innes and Booher (2000). The collaborative governance analysis explains that there are 3 strategic aspects as a prerequisite for the creation of a collaboration process, namely:

- Dimensions of stakeholder participation, as citizen power as stated in the ladder of participation according to Arnstein;

- Dimensions of equal power, there is no domination by certain parties, each actor in dialogue is not hindered by hierarchical boundaries, and there is mutual respect;

- The competent stakeholder / actor dimension that enables consensus-oriented dialogue requires supporting actors, in the sense of having competence in 
communicating, understanding the substance, and having an orientation to achieve goals for the common interest.

\section{RESULTS AND DISCUSSION}

The development of a macro planning approach in policy making, both transactive, collaborative, communicative, participatory deliberative planning, and consensus planning, has a relatively similar emphasis on emphasizing the importance of collaboration based on communication between stakeholders, including the community. (Friedman,2011; Balogh,2011). Some experts describe the collaborative process as an adaptive system process in which different opinions from various parties ultimately produce a consensus ((Friedman,2011). The collaborative process mapping study conducted by Anshell and Gash (2008) is a collaborative mapping that starts with face-to-face dialogue, trust building, commitment to the process, shared understanding, then the formation of intermediate outcomes. Through a dynamic network model, it further strengthens the importance of the collaborative process through collaborative networks that have diversity, interdependence and authentic dialogue with an emphasis on: first, collaborative networks with a diversity of actors; second, actor actors are in a situation of being able to meet each other's interests and are aware of the interdependence between them; third, there is an authentic dialogue where communication flows through the network accurately and reliably among stakeholders with patterns of reciprocity, relationship, learning, creativity, and results in adaptation of existing systems (Innes and Booher,2010).

Several collaborative governance comparative studies conducted in the Republic of Croatia, Malaysia, Nigeria, and India have various forms, adapted to local dimensions, which can take the form of either public private partnership and public community partnership (Graci,2013). Collaborative governance is an adaptive system process in which different opinions from various parties ultimately produce a consensus. Using analysis reference from Ansell and Gash ( 2008), Innes and Booher (2000), Therefore, it is necessary to compile several prerequisites for the creation of a collaborative process, namely: Dimensions of stakeholder participation, as citizen power as stated in the ladder of participation according to Arnstein; Dimensions of equal power, there is no domination by certain parties, each actor having a dialogue is not hindered by hierarchical boundaries, and there is mutual respect; The competent stakeholder / actor dimension that enables consensus-oriented dialogue, requires supporting actors, in the sense of having competence in communicating, understanding the substance, and having an orientation to achieve goals for the common interest.

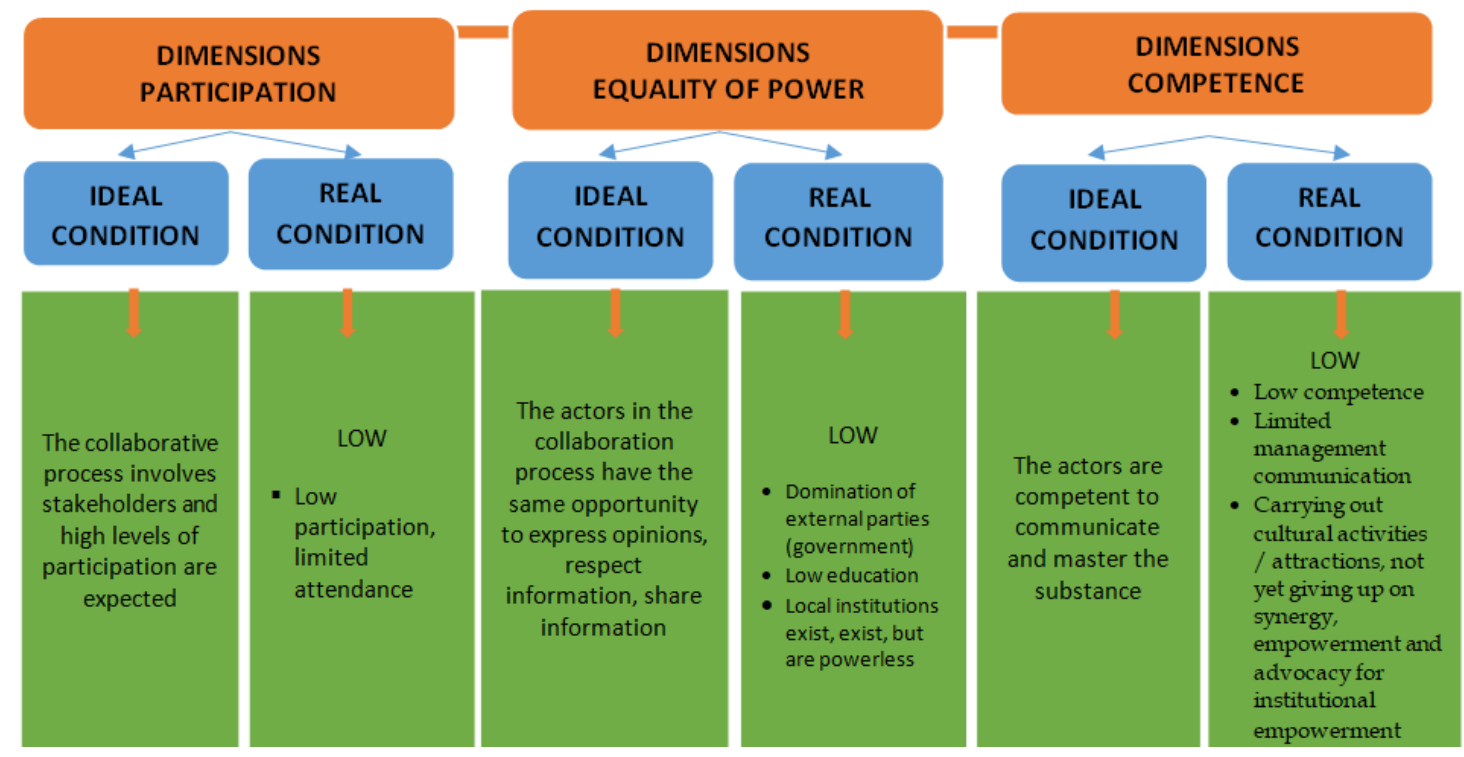

Figure 1 -Collaborative Governance (Source: Olah Data, Tresiana and Duadji, 2018) 
Figure 1 shows the important dimensions of collaborative governance. The study, which was conducted in Teluk Kiluan, as one of the tourism sectors in Indonesia, illustrates the need for active participation of the community through representatives and the ability of actors in dialogue. Collaborative processes cannot be realized in communities that have low levels of community participation, unsupportive leadership. Factors in the form of cultural issues and the level of community education are important aspects of participation in development planning through deliberations on regional planning and development (Tresiana and Duadji, 2016). The study of regional / village development planning consultations in South Lampung and Pesawaran, Indonesia explained several weaknesses including the main government actors, limited stakeholder participation, the nature of formal meetings, the content of policy socialization meetings, the existence of passive local institutions, procedural implementation mechanisms with a committee from government elements (Duadji and Tresiana, 2016).

The government, of course, does not only rely on internal capacity in implementing a policy and its implementation. Limited capabilities, resources, networks are the driving force for collaborative cooperation (Stoddart,2020). Using the important dimension parameters as a prerequisite for collaborative governance, the three of them become the basis and guarantee for the sustainability of tourism governance. The sustainability aspect of the precollaboration process requires a process of identifying problems and identifying stakeholders / actors. Aspects of part of the collaborative process consist of the ability to build trust, build mutual understanding, produce joint problem solving efforts, build mutual commitment (Anshel and Gash,2008).

The strategic dimension of collaborative governance is a process that involves various stakeholders who should be bound, carrying out their respective interests in achieving common goals (Ngar-yin and Hills, 2010), as a process and structure in the formulation of public policy decisions which ideally involve actors constructively coming from all levels, both government, public, private and community levels (Balogh et all.,2011). Studies conducted in Indonesia describe collaborative as a collective and egalitarian process, with participants having substantive authority in decision making and the same opportunity to reflect on their aspirations, in detail through collaborative governance, so there is a common vision, goals, strategies and activities of the parties, they still have authority, but subject to mutual agreement. Continuous implementation in collaborative collaboration of the parties involved consciously carrying out alignment, shared vision and overall liabilities based on mutual agreement (Dwiyanto,2011,Wahyudi et all.,2013). .

Sustainable tourism development governance policies require a change in approach. The idea of a policy based on community development corrects a development model that is not based on collaboration (Cascante and Brennan,2011; Hanafiah et all,2016). The previous bureaucratic model has marginalized and marginalized society. Recommendations in the form of collaboration through strengthening the community side, are believed to not only produce new products that are beneficial to the community, and are in accordance with the needs of the community but also in accordance with sustainable development (Graci, 2013; Khalid et all.,2019). Development policies, previously tourism with a centralized (top down) logic, became irrelevant to the situation in the era of democracy and reform. Management that only relies on investors has proven to weaken the community. Community developmentbased policy corrections relate to efficiency in terms of financing and effectiveness in terms of results, including determining the position of the community and government, so that both parties can play an optimal and synergistic role. Relevance 4 studies explain the importance of the position of community and government as an important part of collaboration. The study of strengthening the state is related to building strength, in a win-win scheme, which means that strengthening the state does not mean weakening the community, but opens space for strengthening for society, because both must be equally strong as pillars of development (Fukuyama,2005). The study of dynamic governance explains that strengthening the state is related to the operation of the various policies, institutions and structures that have been chosen so that they can adapt to the uncertainty and rapid environmental changes so that these policies, institutions and structures remain relevant and effective in achieving the long- 
term desires of society (Geraldine,2007). Both studies clarify the success of sustainable tourism development through adjusting the dynamics of various policies, institutional strategies and programs through strengthening community potential. Social studies reinforce the need for reproduction of social capital in the form of trust, believe and vertrauen (deeprooted trust) containing social glue whose function is to maintain the unity of group members as a unit (Fukuyama and Ikenberry,1996). Last study which conducted by Denhardt and Denhardt (2007), describes the success of tourism governance through community and organizational humanism. The four studies give birth to a thesis, a strong government is a government that can produce policies through dynamic collaborative management of development, with policies that are in line with global issues (sustainable development), national issues (democratization) and based on community strengthening (Community development).

\section{CONCLUSION}

The elaboration of strategic dimensions in the form of participation, equality and community competence as important actors in collaborative governance is an important and strategic dimension in tourism sustainability.

Several important factors such as local culture, community education level, government dynamics in responding to change, deliberations for planning and regional development are useful in improving decision making in public policy.

\section{REFERENCES}

1. Ansell, C. and Gash, A.(2008). Collaborative Governance in Theory and Practice,. Journal of Publik Administration Research and Theory, 18, 543-571

2. Balogh, $S$ et all.(2011). An Integrative Frameworks for Collaborative Governance. Journal of Public Administration Research and Theory, 22, 1-29

3. Cascantea,D.M and Brennanb,M.A . (2012). Conceptualizing community development in the twenty-first century. Community Development, 43 (3), 293-305.

4. Denhardt, J.V. and Denhardt, R. B,. (2007). The New Public Service: Serving, Not Steering, (Expanded Edition). New York: M.E. Sharpe.

5. De Araujo, L.M and Bramwell,B . (1999). Stakeholder Assessment and Collaborative Tourism Planning: The Case of Brazil's Costa Dourada Project. Journal of Sustainable Tourism, 7 (3-4), 356-378

6. Duadji, N and Tresiana, N. (2016). Modelling Forum Musrenbang Desa in Lampung Selatan and Pesawaran Regency. Jurnal Kajian Politik and Masalah Pembangunan, 12 (2), 1829-1844.

7. Duadji, N and Tresiana, N. (2018). Social Entrepreneur Model for Tourism Development in Kiluan Bay. Mimbar Journal, 34 (1), 83-92.

8. Dwiyanto, A. (2011). Manajemen Pelayanan Publik: Peduli, Inklusif, and Kolaboratif. Yogyakarta: UGM Press.

9. Fukuyama, G,J and Ikenberry. (1996). Trust: The Social Virtues and the Creation of Prosperity. Foreign Affairs,75(2), 143

10. Fukuyama, F. (2005). Memperkuat Negara. Jakarta: Gramedia

11. Graci,S ,.(2013). Collaboration and Partnership Development for Sustainable Tourism. Journal Tourism Geographies : An International Journal of Tourism Space, Place and Environment, 15 (1), 25-42

12. Hanafiah, M.H, et all, (2016). Responsible Tourism Practices and Quality of Life: Perspective of Langkawi Island communities. Procedia - Social and Behavioral Sciences, 222, $406-413$

13. Innes, J.E. and Booher, D.E. (2010). Beyond Collaboration Democratic Governance for a Resilient Society dalam Planning with Complexity Complexity, An Introduction to collaborative rationality or public policy. Routledge, Oxon. 
14. John, F. (2011). Insurgencies, Essay in Planning Theory. London and New York: Routledge

15. Kizito Uyi Ehigiamusoe,K.U. (2020).Tourism, growth and environment: analysis of nonlinear and moderating effects. Journal of Sustainable Tourism, 28 (8), 1174-1192

16. Khalid, S, et all,. (2019). Community Empowerment and Sustainable Tourism Development: The Mediating Role of Community Support for Tourism, 11, 1-14.

17. Mark C. J. Stoddart,M.C.J,. (2020). Collaboration gaps and regional tourism networks in rural coastal communities. Journal of Sustainable Tourism , 28 (4), 625-645.

18. Neo, B.S and Geraldine, C.2007. Dynamic Governance: Embedding Culture, Capabilities and Change in Singapore. Singapore: World Scientific Publishing Co. Pte. Ltd.

19. Ngar-yin, D and Hills, P. 2010. Collaborative Governance for Sustainable Development: Wind ResourceAssessment in Xinjiang and Guangdong Province. China: John Wiley\&Sons, Ltd and ERP Environment Wiley Online Library.

20. Tresiana, N. (2015). Rationality District Policy Proliferation and Villages in Town Bandar Lampung. Jurnal Bina Praja, 7 (2), 161 - 172

21. Tresiana, $\mathrm{N}$ and Duadji, N,. (2016). Kegagalan Pemaknaan Lembaga Musyawarah Perencanaan and Pembangunan Desa dalam mewujudkan Deepening Democracy. Jurnal Masyarakat, Kebudayaan and Politik Unair. 29(4),191-203

22. Wahyudi, K. (2013). Transformasi Pelayanan Jakarta Commuter Line: Studi Tentang Collaborative Governance di Sektor Publik. Yogyakarta: UGM Press. 